\title{
CALCULATION ESTIMATION OF OVERVOLTAGE ON INSULATION OF THE EQUIPMENT OF A SUBSTATION AT THE LIGHTNING STRIKE IN ITS LIGHTNING ARRESTER
}

Purpose. The complex approach to calculating thunderstorm overvoltage on substation equipment is considered when lightning strikes in a lightning rod. Methodology. The conditions of safe passage of lightning current through a lightning arrester are formulated. Results. It is shown that the calculation of the permissible length of air insulating gaps in the substation is based on the breakdown of the air tension, which is assumed to be $500 \mathrm{kV} / \mathrm{m}$. This leads to an error in calculating the length of the air gap and, as a consequence, the probability of its breakdown, the value of which is used to calculate the indicator of the lightning resistance of the substation. A technique is proposed for calculating the permissible voltage on the transformer case when a lightning strike strikes the lightning receptacle of the transformer portal. On the basis of the nonlinear pulsed electric strength of the ground, the specified minimum permissible ground distance between the grounding rod of the lightning rod and the nearest point of the protected device is obtained. Originality. Refined calculation of the length of the minimum breakdown gap in the air and in the ground. Practical value. The proposed approach makes it possible to calculate thunderstorm overvoltage on substation equipment. References 11, tables 4, figures 6.

Key words: lightning overvoltage, substation, lightning arrester, volt-second characteristic, insulator string, electric field, air gap, permissible voltage, transformer case, pulsed electric strength.

Розроблено інженерний підхід до розрахунку грозових перенапруг на обладнанні підстанцї при ударі блискавки в блискавковідвід. Сформульовані умови безпечного для обладнання проходження струму блискавки по блискавковідводу. Показано, щио розрахунок допустимої довжини повітряних ізоляційних проміжків на підстанцї базується на основі пробивний напруженості повітря, яка прийнята рівною 500 кВ/м. Це призводить до помилки розрахунку довжини повітряного проміжку $i$, як наслідок, ймовірності його пробою, значення якої використовується для розрахунку показника грозоупорності підстанції. Як приклад розглянута методика розрахунку допустимої напруги на корпусі трансформатора при ударі блискавки в блискавкоприймач трансформаторного порталу. На основі нелінійної імпульсної електричної міцності трунту отримано уточнену мінімально допустиму відстань в землі міжс заземлювачем блискавковідводу і найближчою до нього точкою пристрою, щи захищається. Наводяться аналітичні вирази для розрахунків. Бібл. 11, табл. 4, рис. 6

Ключові слова: грозові перенапруги, підстанція, блискавковідвід, вольт-секундна характеристика, гірлянда ізоляторів, електричне поле, повітряний проміжок, допустиме напруження, корпус трансформатора, імпульсна електрична міцність.

Разработан инженерный подход к расчету грозовых перенапряжений на оборудовании подстанции при ударе молнии в молниеотвод. Сформулированы условия безопасного для оборудования прохождения тока молнии по молниеотводу. Показано, что расчет допустимой длины воздушных изоляционных промежутков на подстанции базируется на основе пробивной напряженности воздуха, которая принята равной 500 кВ/м. Это приводит к ошибке расчета длины воздушного промежутка и, как следствие, вероятности его пробоя, значение которой используется для расчета показателя грозоупорности подстанции. В качестве примера рассмотрена методика расчета допустимого напряжения на корпусе трансформатора при ударе молнии в молниеприемник трансформаторного портала. На основе нелинейной импульсной электрической прочности грунта получено уточненное минимальное допустимое расстояние в земле между заземлителем молниеотвода и ближайшей к нему точкой защищаемого устройства. Приводятся аналитические выражения для расчетов. Библ. 11, табл. 4, рис. 6

Ключевые слова: грозовые перенапряжения, подстанция, молниеотвод, вольт-секундная характеристика, гирлянда изоляторов, электрическое поле, воздушный промежуток, допустимое напряжение, корпус трансформатора, импульсная электрическая прочность.

Introduction and problem definition. On the globe, as noted in [1], there are at the same time about 2000 thunderstorm foci, in which about 100 lightning discharges occur every second. Many countries, including Ukraine, have thunderstorm maps that are based on longterm meteorological observations and are periodically updated. This allows to improve the methods for calculating lightning overvoltage in electrical installations. Analysis of studies and publications shows that the task of protecting electrical equipment of substations (SS) from thunderstorm overvoltage during direct lightning strikes is under consideration of many domestic and foreign scientists. Coordination of insulation under conditions of limiting overvoltage, as well as reflection of modern materials on the problem under consideration are presented in [2]. The operation of insulating structures at lightning and internal overvoltage in electrical systems and their limitation are considered in [1]. However, the continued research of many scientists leads to the need to improve calculations to limit lightning overvoltage. To determine the length of the insulating air gap $l_{\text {a.g }}$ between the support or portal body and the flexible bus or equipment, dependency curves $U_{50 \%}=f\left(l_{\text {a.g }}\right)$ are often used. The dependence of the $50 \%$ discharge voltage of the air gap on its length at positive and negative polarity of lightning pulses is given, for example, in [3]. These dependencies have a weak nonlinearity. Consequently, the value of the breakdown electric field 
strength of air in long air gaps decreases with an increase in their length which must be taken into account in the calculations when determining the length of the gap. Not accounting of this, i.e. the adoption of the value of the permissible electric field strength in the air gap constant and equal to $500 \mathrm{kV} / \mathrm{m}$ can lead to inaccuracy in determining its length and, accordingly, to reduce it, which increases the probability of breakdown of the specified gap. In addition, the neglect of possible overlaps of the air insulation of the substation after the end of the current increase leads to an underestimation of the danger of lightning currents with relatively low amplitudes at a large slope and the duration of their pulses [4]. More accurate results for determining the dielectric strength of the insulation under the so-called non-standard voltages can be obtained using the methods described in [5-7], which also makes it possible to clarify the lengths of the discharge gaps.

The goal of the paper is the development of an engineering methodology for calculating lightning overvoltage on substation equipment at a lightning strike in its lightning arrester.

Formulation of conditions for limiting thunderstorm overvoltage and their implementation. The intensity of thunderstorm activity in the location of the protected object is characterized by the average number of thunderstorm hours per year $N_{l . h}$. Another characteristic of thunderstorm activity is the average number of lightning strikes $n_{l s}$ per $1 \mathrm{~km}^{2}$ of the earth's surface per 100 thunderstorm hours. On the territory of Ukraine $n_{l s}=6.71 / \mathrm{km}^{2}$ per 100 thunderstorm hours.

Protecting objects from direct lightning strikes is performed using lightning arresters of various designs. A lightning arrester is a device towering above the protected object, through which the lightning current, bypassing the protected object, is diverted into the ground. A lightning arrester consists of a lightning rod, directly receiving a lightning strike, a down-conductor (mast, gantry, rack fitting, strip) and a grounding device (GD). These extended elements have an inductance that also determines the distribution of the voltage along them. In addition, the resistance of the GD depends on its geometric dimensions and the specific resistance of the soil ground $\rho$ in which it is located, as well as on the parameters of the lightning current pulse: oblique front, front slope $a$, front duration $\tau_{f}$, pulse duration $\tau_{p}$, amplitude $I_{l}$. When lightning current flows from the GD, the current density through the grounding rods is high, so high electric field strengths are created in the ground at the surface of the electrodes, exceeding the ground breakdown strength $E_{b}$. Zones of high conductivity are formed around the electrodes (primarily due to ionization processes, a dense network of streamers, etc.), increasing their effective dimensions. As a result, the resistance of the GD decreases. The rapid increase in lightning current at the pulse front creates a voltage drop across the inductance of an extended GD, which limits current drainage from more distant parts of it. In this case, the resistance of the GD, on the contrary, increases. As a result of the influence of one or another factor (the formation of an ionization zone and streamer channels or a voltage drop across the inductance), the resistance of the GD to the lightning current flowing down from it $R_{p}$ (without taking into account of inductance) or $Z_{p}$ (taking into account of inductance) differs from GD resistance to power frequency current $R_{g}$ measured at alternating voltage and relatively small current.

The resistance of the horizontal GD to the current of power frequency $R_{g}$ is determined by the well-known formula [8]:

$$
R_{g}=\frac{\rho}{2 \pi \cdot l} \cdot\left[\ln \frac{l^{2}}{2 r \cdot h_{g}}+0.5 \ln \left(1+\frac{4 h_{g}^{2}}{l^{2}}\right)\right],
$$

where $l$ is the GD length, $\mathrm{m} ; r$ is the GD radius, $\mathrm{m} ; h_{g}$ is the GD depth of laying in the ground, $\mathrm{m}$.

The resistance of a horizontal beam GD to pulsed current (of lightning) at the point of entry of lightning current for its instant of its maximum is calculated using the approximate formula [9]:

$$
Z_{p}\left(0, \tau_{f}\right)=\frac{R_{g}+\frac{L_{0} \cdot l}{3 \cdot \tau_{f}}}{n \cdot \eta},
$$

where $L_{0}$ is the specific inductance (per unit length of the GD electrode, $\mu \mathrm{H} / \mathrm{m}) ; n$ is the number of horizontal beams; $\eta$ is the mutual shielding factor.

The maximum voltage at the point of entry of lightning current to the GD is calculated by the formula:

$$
U_{\max }=I_{l} \cdot Z_{p}\left(0, \tau_{f}\right) .
$$

The voltage at the end of the horizontal GD when lightning current enters its beginning is calculated by the formula [9]:

$$
U\left(l, \tau_{f}\right)=\frac{I_{l}}{n} \cdot\left(R_{g}-\frac{L_{0} \cdot l}{6 \cdot \tau_{f}}\right) .
$$

The relative decrease in voltage at the end of the horizontal GD depending on its length is calculated by the formula:

$$
X \%=\frac{U\left(l, \tau_{f}\right)}{U_{\max }} \cdot 100 \% .
$$

Protection of outdoor switchgear for $110 \mathrm{kV}$ and more from direct lightning strikes is usually performed with rod lightning arresters, lightning rods of which, as a rule, are installed on the outdoor switchgear structures. The installation of lightning rods on portals located near transformers or shunt reactors is allowed if a number of requirements are met. First of all, the lightning current spreading from the point of connection of the current release to the GD of the SS should be provided not less than in two or four directions of grounding lines. Secondly, two or three vertical electrodes with a length of 3-5 m should be installed at a distance of not less than the electrode length along the grounding line from the point of connection of the current release. It is known [9] that when exposed to pulsed lightning currents, there is a decrease in the proportion of current flowing from distant grounding sites, i.e. non-equipotentiality occurs, which increases with the length of the electrode. This phenomenon is associated with the value of the inductance of the steel electrode and its dependence on the equivalent frequency and amplitude of the flowing 
current. The specific inductance of the grounding electrode of the GD is determined by the well-known formula $[1,9,10]$ :

$$
L_{0}=0.2 \cdot\left[\ln \left(\frac{2 l}{d}-0.31\right)\right],
$$

and the total inductance of an electrode of length $l$ in this case is determined as

$$
L_{e}=L_{0} \cdot l \text {. }
$$

Passing the lightning current through a lightning arrester on the SS will be safe for the equipment if it is based on the following calculations.

Calculation of permissible overvoltage on the insulator string. The pulsed discharge voltage of the insulator string must be greater than the voltage that arises during operation between the point of attachment of the string to the portal and the point of attachment of the flexible tire to the string. This means that the allowable voltage that occurs on a string of insulators during its operation must lie below the volt-second characteristic of the string, determined by the well-known formula [1]:

$$
U(t)=A \cdot \sqrt{1+\frac{T_{0}}{t}},
$$

where $t$ is the time, $\mu \mathrm{s} ; A$ and $T_{0}$ are the constants.

The values of the constants are determined by substituting in (8) of the test voltages with full (at $t=10$ $\mu \mathrm{s})$ and cut (at $t=2 \mu \mathrm{s}$ ) pulses. Thus, for example, for a $110 \mathrm{kV}$ string of seven ПC12-A insulators, we have test voltages $U_{2 \mu \mathrm{s}}=600 \mathrm{kV}$ and $U_{10 \mu \mathrm{s}}=480 \mathrm{kV}$. Substituting these values into formula (8), we obtain a system of two equations with unknown constants $A$ and $T_{0}$. Based on the solution of this system of equations with respect to the constants $A$ and $T_{0}$, the volt-second characteristic of the string is described by the expression:

$$
U(t)=444.994 \cdot \sqrt{1+\frac{1.636}{t}} .
$$

The reverse overlap of the insulator string on the portal with the lightning rod occurs at critical current $I_{c}$, which is found from the equality of the portal potential and the $50 \%$ pulse discharge voltage of the insulator string according to the formula [1]:

$$
I_{c} \cdot R_{p}+a \cdot L_{0} \cdot h=U_{50 \%},
$$

where $R_{p}$ is the resistance of the GD of the substation to pulsed current (of lightning); $h$ is the height of the fixing point of the string on the portal.

The critical value of the current $I_{c}$, at which the reverse overlap of the insulator string occurs, is obtained from the expression (10) in the following form:

$$
I_{c}=\frac{U_{50 \%}-a \cdot L_{0} \cdot h}{R_{p}} .
$$

Calculation of the permissible length of air gaps. The shortest distance in the air between the lightning arrester and the substation equipment nearest to it should be not less than permissible. The calculation of this distance is based on the determination of the maximum potential at a specific point of the lightning arrester (mast, portal, or separately laid current-carrying release), which is located at distance $h_{1}$ from the connection point of the current release (portal) to the GD of the SS. For the considered form of a lightning current pulse, the maximum potential at a particular point of a lightning arrester occurs at the time of the maximum lightning current and is determined by the formula

$$
U_{\text {max }}=I_{l} \cdot R_{p}+a \cdot L_{T} \cdot h_{1} .
$$

where $L_{T}$ is the inductance of a unit length of the current release.

In engineering calculations, the specific value of $L_{T}$ is assumed to be $L_{T}=1.7 \mu \mathrm{H} / \mathrm{m}$ for both the separately laid current-carrying release and for metal lightning arresters of a lattice design. Voltage $E_{a} \cdot l_{a}$ is applied to the air gap of $l_{a}$ length, where $E_{a}$ is the permissible electric field strength in the air.

Since the number of lightning strikes in SS is relatively small, in (12) as the calculated values of the parameters $I_{l}$ and $a$ the following numerical values are taken: $I_{l}=60 \mathrm{kA}$ and $a=30 \mathrm{kA} / \mu \mathrm{s}$. In addition, the permissible electric field strength in air $E_{a}$ is taken in calculations to be $500 \mathrm{kV} / \mathrm{m}$. Based on the above, the shortest distance through the air can be written as follows:

$$
l_{a} \geq \frac{I_{l} \cdot R_{p}+a \cdot L_{T} \cdot h_{1}}{E_{a}} .
$$

Substituting the above values into the formula (13), we obtain the permissible distance in air

$$
l_{a} \geq \frac{60 \cdot R_{p}+30 \cdot 1.7 \cdot h_{1}}{500} \approx 0.12 \cdot R_{p}+0.1 \cdot h_{1} .
$$

For example, when $R_{p}=10 \Omega$ and $h_{1}=10 \mathrm{~m}$ from (14) we find that $l_{a}=2.2 \mathrm{~m}$. It is well known that the air gap, which has uniform electric field, has the greatest electrical strength. If the considered gap has uniform electric field at small distances, then, with the same electrodes, an increase in the distance between them leads to an increase in the inhomogeneity of the electric field, and with a further increase in the distance, the electric field in the gap becomes highly heterogeneous. Consequently, at large distances between the electrodes, the breakdown electric field strength of air in the gap decreases [3], i.e. to prevent breakdown, an increase in the distance between the electrodes is necessary. Therefore, when the distances between the electrodes, measured by meters, used in practice the numerical value of the breakdown electric field strength of air of $500 \mathrm{kV} / \mathrm{m}$ should be refined. The longer the air gap, the smaller this value will be. A preliminary assessment shows that an increase in the length of this gap leads to a nonlinear decrease in the breakdown electric field strength.

For example, for a breakdown of an air gap of $6 \mathrm{~m}$ in length with breakdown electric field strength of $500 \mathrm{kV} / \mathrm{m}$, voltage of $3000 \mathrm{kV}$ must be applied. However, proceeding from the curves $U_{50 \%}=f\left(l_{\mathrm{a} . \mathrm{g}}\right)$ [3], the breakdown of such a gap will occur at voltage of about $2834 \mathrm{kV}$, i.e. at voltage of $5.5 \%$ less. Here, the breakdown electric field strength of air in the considered gap will be $472.3 \mathrm{kV} / \mathrm{m}$. Based on the breakdown electric field strength of air of $472.3 \mathrm{kV} / \mathrm{m}$, we determine the allowable distance by air by the formula (13), which is $2.31 \mathrm{~m}$, which is $11 \mathrm{~cm}$ (or $5 \%$ ) more than at the accepted electric field strength of $500 \mathrm{kV} / \mathrm{m}$. 
Calculation of the allowable voltage on the transformer case. The shortest distance along the GD line from the point of connection of the current release (portal) to it to the point of connection to the GD of the transformer case must be not less than the permissible value. The fulfillment of this condition is investigated by calculating the voltage on the case of a transformer connected to the GD of the SS, with different specific ground resistance and lightning pulse parameters.

As an example, consider a $110 / 6 \mathrm{kV}$ power transformer, which is installed at the transformer portal.

To ensure the specified reliability of the transformer during the thunderstorm season, it is necessary to determine the distance $L$ along the line of the GD electrode from the point of connection of the current release of the lightning arrester to the grounding point of the transformer case at which the voltage on the case does not exceed the allowable value (dielectric strength of external insulation). In this case, as the allowable voltage, we take the test voltage of the external insulation of a power transformer with lightning pulses. Test voltages of electrical equipment during thunderstorm pulses, reduced to normal atmospheric conditions, are presented in Table 1. Here, the numerator represents the value of the total pulse, and the denominator presents the value of the cutoff one.

Table 1

Test voltages of lightning pulses [1]

\begin{tabular}{|c|c|c|}
\hline \multicolumn{2}{|c|}{$\begin{array}{c}\text { Acting voltage value, } \\
\mathrm{kV}\end{array}$} & $\begin{array}{c}\text { Maximum value of the thunderstorm } \\
\text { pulse, } \mathrm{kV}\end{array}$ \\
\hline Class & $\begin{array}{c}\text { Maximum } \\
\text { working }\end{array}$ & $\begin{array}{c}\text { Power, voltage and current } \\
\text { transformer, reactor, apparatus }\end{array}$ \\
\hline 3 & 3.6 & $42 / 50$ \\
\hline 6 & 7.2 & $57 / 70$ \\
\hline 10 & 12 & $75 / 90$ \\
\hline 15 & 17.5 & $100 / 120$ \\
\hline 20 & 24 & $120 / 150$ \\
\hline 35 & 40.5 & $185 / 230$ \\
\hline 110 & 126 & $460 / 570$ \\
\hline
\end{tabular}

We calculate the voltage on the transformer case when a lightning strikes a lightning rod located on the transformer portal. The transformer case is connected to the grid of the grounding device, which is made of steel bar of circular cross section with a diameter of $d=2 r=12$ $\mathrm{mm}$, the depth of $h_{g}=0.7 \mathrm{~m}$. Let the soil resistivity is $\rho=100 \Omega \cdot \mathrm{m}$, and the amplitude of the lightning current pulse is $I_{l}=20 \mathrm{kA}$ with the duration of its front $\tau_{f}=2 \mu \mathrm{s}$. The length of the beam $l$ of the GD varies from 3 to $21 \mathrm{~m}$. The height of the lightning arrester is $h_{l r}=19.35 \mathrm{~m}$.

Perform the calculations for three cases:

1) the current release of the lightning arrester is connected to two oppositely directed beams of the grid;

2) the current release of the lightning arrester is connected to the three beams of the grid directed at an angle of $90^{\circ}$ (with the use of GDs in the system (shielding) $\eta_{p}=0.8$ );

3 ) the current release of the lightning arrester is connected to the four beams of the grid (with $\eta_{p}=0.65$ ).
The results of the calculations are given in Table 2-4.

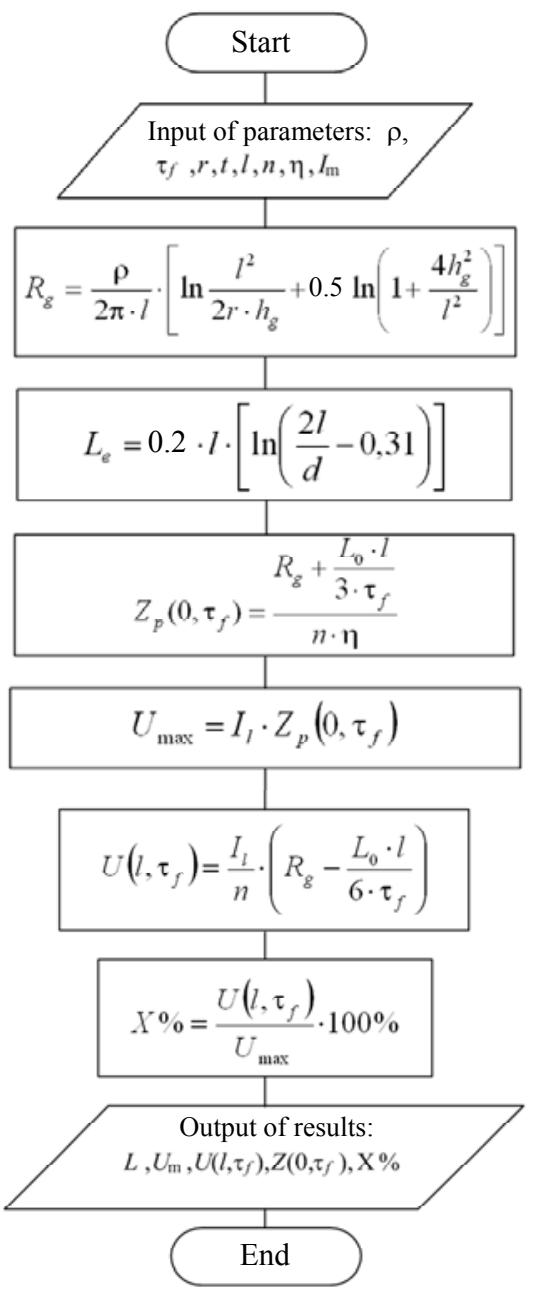

Fig. 1. Block diagram of the algorithm for calculating dependencies of the voltage on the transformer case on the distance of the grounding point of the current release of the lightning release

Table 2

Calculation results for the case of double-beam grounding

\begin{tabular}{|c|c|c|c|c|}
\hline$L, \mathrm{~m}$ & $U_{l}, \mathrm{kV}$ & $U_{\max }, \mathrm{kV}$ & $Z_{p}, \Omega$ & $X, \%$ \\
\hline 3 & 351.492 & 360.408 & 18.02 & 97.526 \\
\hline 6 & 187.853 & 206.909 & 10.345 & 90.79 \\
\hline 9 & 129.254 & 159.676 & 7.984 & 80.948 \\
\hline 12 & 95.783 & 138.082 & 6.904 & 69.367 \\
\hline 15 & 73.031 & 127.59 & 6.379 & 57.239 \\
\hline 18 & 55.878 & 123 & 6.15 & 45.429 \\
\hline 21 & 42.027 & 121.967 & 6.098 & 34.458 \\
\hline
\end{tabular}

Table 3

Calculation results for the case of three-beam grounding

\begin{tabular}{|c|c|c|c|c|}
\hline$L, \mathrm{~m}$ & $U_{l}, \mathrm{kV}$ & $U_{\max }, \mathrm{kV}$ & $Z_{p}, \Omega$ & $X, \%$ \\
\hline 3 & 234.328 & 300.34 & 15.017 & 78.021 \\
\hline 6 & 125.235 & 172.424 & 8.621 & 72.632 \\
\hline 9 & 68.17 & 133.063 & 6.653 & 64.758 \\
\hline 12 & 63.855 & 115.069 & 5.753 & 55.493 \\
\hline 15 & 48.687 & 106.325 & 5.316 & 45.791 \\
\hline 18 & 37.252 & 102.5 & 5.125 & 36.343 \\
\hline 21 & 28.018 & 101.639 & 5.082 & 27.566 \\
\hline
\end{tabular}


The obtained results show the following. For the first case, when the transformer case is connected to the grid at a distance of $15 \mathrm{~m}$ along the grounding line from the current release (portal) connection point to two beams, the atmospheric overvoltage on the case is $73 \mathrm{kV}$, i.e. exceeds $70 \mathrm{kV}$. In this case, the connection of the case to the GD must be performed at a distance of $15.5 \mathrm{~m}$ or more.

Table 4

Calculation results for the case of four-beam grounding

\begin{tabular}{|c|c|c|c|c|}
\hline$L, \mathrm{~m}$ & $U_{l}, \mathrm{kV}$ & $U_{\max }, \mathrm{kV}$ & $Z_{p}, \Omega$ & $X, \%$ \\
\hline 3 & 175.746 & 277.237 & 13.862 & 63.392 \\
\hline 6 & 93.926 & 159.161 & 7.958 & 59.013 \\
\hline 9 & 64.627 & 122.828 & 6.141 & 52.616 \\
\hline 12 & 47.892 & 106.217 & 5.311 & 45.088 \\
\hline 15 & 36.515 & 98.146 & 4.907 & 37.205 \\
\hline 18 & 27.939 & 94.616 & 4.731 & 29.529 \\
\hline 21 & 21.014 & 93.82 & 4.691 & 22.398 \\
\hline
\end{tabular}

For the second case, when the current release of the lightning arrester is connected to the three beams of the grid, and at a distance of $11.03 \mathrm{~m}$ along the grounding line there is a grounding point of the transformer case, the atmospheric overvoltage on the case is $70.026 \mathrm{kV}$, i.e. practically does not exceed $70 \mathrm{kV}$.

For the third case, when the current release of the lightning arrester is connected to the four beams of the grid, and at a distance of $9 \mathrm{~m}$ along the grounding line there is a ground point of the transformer case, the atmospheric overvoltage on the case is about $64.63 \mathrm{kV}$, i.e. does not exceed $70 \mathrm{kV}$.

As you can see, at the same lightning current at the point of entry into the GD of the SS with increasing number of beams at $\rho=100 \Omega \cdot \mathrm{m}$, the GD resistance to the pulsed current decreases. In addition, with increasing $\rho$ from $50 \Omega \cdot \mathrm{m}$ to $500 \Omega \cdot \mathrm{m}$ with the number of beams $n=4$ and lightning current $I_{l}=20 \mathrm{kA}$, the indicated resistance also increases. Similar results were obtained for other currents, too, for example $I_{l}=60 \mathrm{kA}$.

Figure 2 shows the dependencies of the voltage at the GD point under consideration on the distance $L$ to the point of current input.

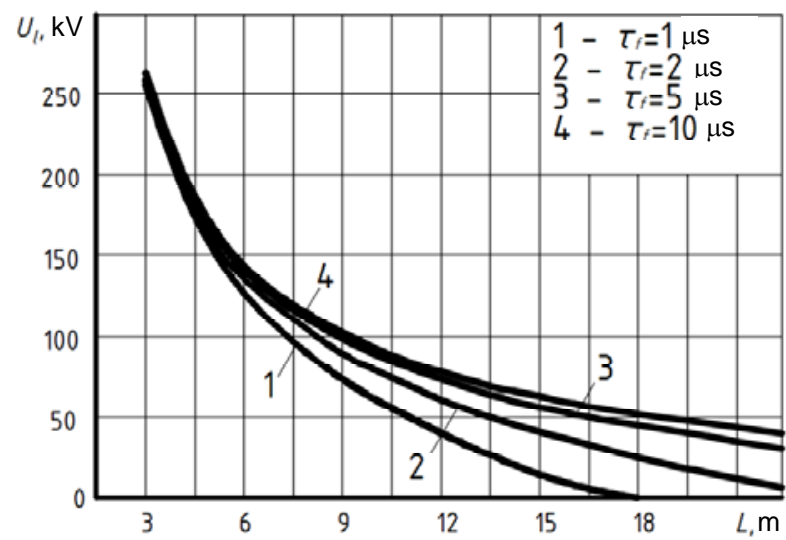

Fig. 2. Dependence of the voltage at the considered GD point at distance $L$ from the point of input of the lightning current $I=20 \mathrm{kA}$ for different values of its front length
Figure 3 shows the dependencies of the voltage at the considered GD point on the distance $L$ to the point of input of the lightning current for different values of its amplitude, but with a constant current front length $\tau_{f}=2 \mu \mathrm{s}$.

As follows from Fig. 2, 3, as the distance $(L, \mathrm{~m})$ from the point of input of the lightning current into the GD along the beam of the grounding conductor line is removed, the potential $U_{l}$ decreases in all the considered cases. In this case, the rate of descent depends both on the amplitude of the lightning current and on the steepness of its front.

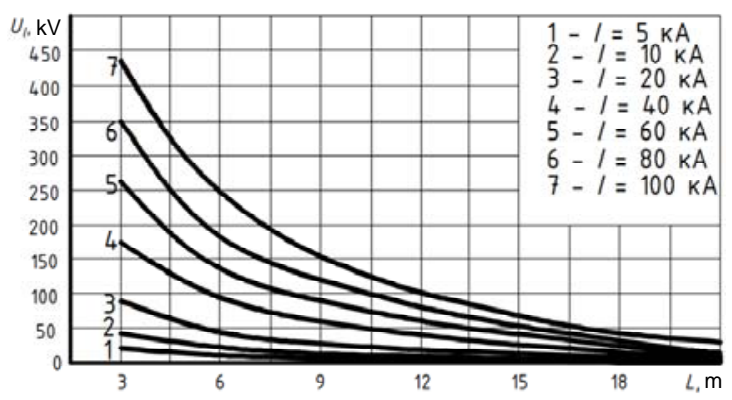

Fig. 3. Dependencies $U_{l}=f(L)$

Figure 4 shows the dependencies of the resistance of the GD of the SS to the pulsed current at the input point (4 beams) of the lightning current on radius of its spreading along lines (length of beams $L$ ) and the length of the front of the lightning current.

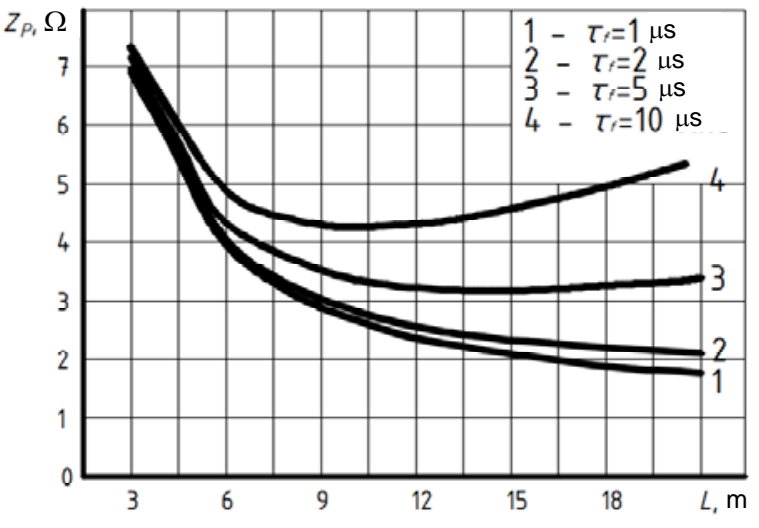

Fig. 4. Dependencies $Z_{p}=f(L)$

Analysis of the results presented in Fig. 4, shows that the resistance $Z_{p}$ of the GD of the lightning arrester of the SS to the pulsed current depends complexly on the size of the spreading zone of the lightning current at the time of its maximum at different values of the front length. For example, at $\tau_{p}>2 \mu$ s, the resistance $Z_{p}$ decreases with increasing size $L$ of the zone. At the lightning current of $60 \mathrm{kA}$ and the ground resistivity $\rho=50 \Omega \cdot \mathrm{m}$, the curves $Z_{p}=f(L)$ monotonously decrease, and as $\tau_{f}(\leq 2 \mu \mathrm{s})$ decreases, the resistance $Z_{p}$ first decreases and then begins to increase, while the minimum $Z_{p}$ value shifts towards lower values of $L$.

Figure 5 presents the dependence $L=f(n)$, which shows a decrease in the zone of spreading the lightning current with an increase in the number of beams of the GD. In this case, the voltage at the boundary of the zone is maintained at the level of the permissible $70 \mathrm{kV}$. 


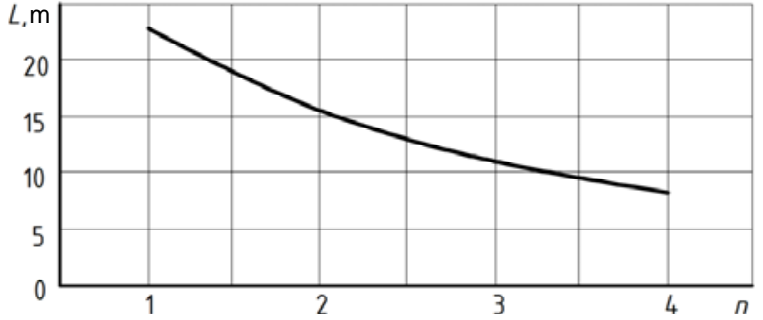

Fig. 5. Dependence of the radius $(L)$ of the lightning current spreading zone along lines of the GD of the SS on the number of beams $n$ at the point of current input

Let us calculate the number of years of operation of the transformer without strike, during which the voltage on its case, caused by atmospheric overvoltage, does not exceed the permissible $70 \mathrm{kV}$ :

$$
N=\frac{1}{N_{l . s} \cdot P_{I_{l}}},
$$

where $N_{l s}=\pi\left(3,5 \cdot h_{l r}\right)^{2} \cdot 10^{-6} \cdot \sigma \cdot N_{t h}$ is the number of lightning strikes in the lightning arrester of the SS; $h_{l r}$ is the height of the lightning arrester, $\mathrm{m} ; \sigma=0.067$ $1 /(\mathrm{km})^{2} \cdot$ lighting hours; $N_{t h}=60$ lighting hours;

$$
N_{l s}=3,14 \cdot(3,5 \cdot 19,35)^{2} \cdot 10^{-6} \cdot 0,067 \cdot 60=0,058 \text {. }
$$

The probability that the amplitude of the lightning current exceeds the value of $I_{l}$ is calculated by the formula

$$
P_{I_{l}}=10^{-I_{l} / 60} \text {. }
$$

For the lightning current $I_{l}=60 \mathrm{\kappa A} \mathrm{we} \mathrm{obtain}$

$$
P_{I_{l}}=10^{-60 / 60}=0.1 \text {. }
$$

Thus, substituting the values obtained above into formula (15), we obtain the number of years of operation of the transformer without strike:

$$
N=\frac{1}{0,058 \cdot 0,1}=172,634 \text { year. }
$$

If the amplitude of the lightning current exceeds $60 \mathrm{kA}$, the overvoltage will be more than $70 \mathrm{kV}$. To avoid this, protective devices (surge arresters or surge suppressors) are used.

The calculations performed using this algorithm are shown in Fig. 6. The curve of the dependence of the number of years during which the value of the lightning current may be greater than the specified one, as follows from Fig. 6, increases nonlinearly.

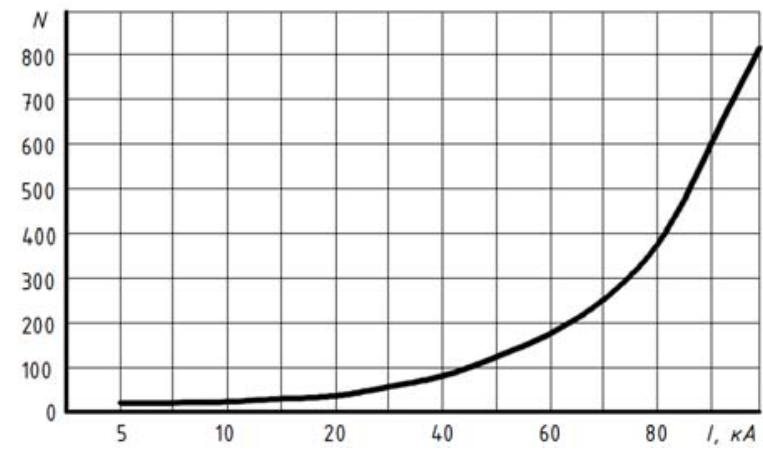

Fig. 6. Dependence $N=f\left(I_{l}\right)$

Calculation of the length of the permissible gap in the ground. For a free-standing lightning arrester, the shortest distance in the ground between the GD of the lightning arrester and the nearest to it point of the protected device in the ground must be not less than the permissible value.

Assuming that in the ground voltage $E_{e} \cdot l_{e}$ is applied to the shortest gap of length $l_{e}$, where $E_{e}$ is the electric field strength permitted in the ground, we write this condition as

$$
l_{e} \cdot E_{e} \geq I_{l} \cdot R_{p},
$$

where $l_{e}$ is the shortest distance in the ground between the GD of the lightning arrester and the nearest to it point of the protected device in the ground; $E_{e}\left(E_{b . g}\right)$ is the pulsed electric strength of the soil (breakdown electric field strength).

From condition (16) we determine the minimum permissible value of $l_{e}$ :

$$
l_{e} \geq \frac{I_{l} \cdot R_{p}}{E_{b . g}} .
$$

The results of the experimental determination of the pulsed electric strength of the soil at NTU «KhPI» showed [11] that this quantity is non-linear, i.e. $E_{b . g}=f(S)=A+\frac{B}{S}$.

For large gaps, measured in tens of centimeters, and even more in meters, the value of $E_{b . g}$ tends to numerical values (100-150) $\mathrm{kV} \mathrm{m}$, depending on the characteristics of the soil.

Substituting in the expression (17) the value $E_{b . g}=$ $=150 \mathrm{kV} / \mathrm{m}$ and $I_{l}=60 \mathrm{kA}$, we obtain the condition

$$
l_{e} \geq 0,4 \cdot R_{p},
$$

which allows to determine the minimum permissible distance in the ground between the grounding conductor of the lightning arrester and the nearest to it point of the protected device.

\section{Conclusions.}

An engineering methodology has been developed for calculating the allowable voltage on the transformer case at a lightning strike in the lightning rod of the transformer portal and the allowable number of years of operation of the transformer during which the voltage on its case caused by atmospheric overvoltage does not exceed the allowable value.

An engineering calculation of lightning overvoltage was performed on the equipment of the substation during a lightning strike to its lightning arrester. The conditions of safe for the equipment of the SS of the passage of lightning current through the lightning arrester are formulated. The performed studies showed that the used value of the pulsed breakdown electric field strength of air of $500 \mathrm{kV} / \mathrm{m}$ leads to an inaccurate determination of the allowable length $l_{a}$ of the air discharge gap (with an error of up to $5 \%$ ). With an increase in the length $l_{a}$ of this gap, the pulsed breakdown electric field strength of air nonlinearly decreases and, as a result, the permissible minimum length of the specified interval increases.

Accounting of the nonlinear pulsed electric strength of the soil allowed to obtain a refined minimum allowable distance $l_{e}$ in the ground between the grounding conductor of the lightning arrester and the nearest to it point of the grounded device. 


\section{REFERENCES}

1. Bazutkin V.V., Larionov V.P., Pintal' Y.S. Tekhnika vysokikh napryazheniy: Izolyatsiya i perenapryazheniya $v$ elektricheskikh sistemakh [High voltage technique. Insulation and surge in electrical systems]. Moscow, Energoatomizdat Publ., 1986. 464 p. (Rus).

2. Gul' V.I., Nizhevskiy V.I., Khomenko I.V. Koordinatsiya izolyatsii i perenapryazheniya $v$ elektricheskikh vysokovol'tnykh setyakh [Coordination of insulation and overvoltage in highvoltage electrical networks]. Kharkiv, EDENA Publ., 2009. 270 p. (Rus).

3. Kuchinskii G.S., Kizevetter V.E., Pintal' Iu.S. Izoliatsiia ustanovok vysokogo napriazheniia [Isolation of installations of high tension]. Moscow, Energoatomizdat Publ., 1987. 368 p. (Rus).

4. Kuklin D.V., Yefimov B.V. Calculation of hazardous parameters curves at high grounding resistance of power line poles. Electricity, 2016, no.6, pp. 16-21. (Rus).

5. Pigini A., Rizzi G., Garbagnati E., Porrino A., Baldo G., Pesavento G. Performance of large air gaps under lightning overvoltages: experimental study and analysis of accuracy predetermination methods. IEEE Transactions on Power Delivery, 1989, vol.4, no.2, pp. 1379-1392. doi: 10.1109/61.25625.

6. Caldwell R., Darveniza M. Experimental and Analytical Studies of the Effect of Non-Standard Waveshapes on the Impulse Strength of External Insulation. IEEE Transactions on Power Apparatus and Systems, 1973, vol. PAS-92, no.4, pp. 1420-1428. doi: 10.1109/tpas.1973.293550.
7. Chisholm W. New challenges in lightning impulse flashover modeling of air gaps and insulators. IEEE Electrical Insulation Magazine, 2010, vol.26, no.2, pp. 14-25. doi: 10.1109/mei.2010.5482551.

8. Burgsdorf V.V., Yakobs A.I. Zazemlyayushchie ustroystva elektroustanovok [Grounding device of electrical installations]. Moscow, Energoatomizdat Publ., 1987. 400 p. (Rus).

9. Ryabkova E.Y. Zazemleniya v ustanovkah vysokogo napryazheniya [Grounding installations high voltage]. Moscow, Energy Publ., 1978. 224 p. (Rus).

10. Kalantarov P.L., Tseytlin L.A. Raschet induktivnostey [Inductance calculations]. Leningrad, Energoatomizdat Publ., 1986. 488 p. (Rus).

11. Nizhevskyi V.I., Gul' V.I. Dielectric strength of limited soil volumes. Bulletin of the Kharkov Polytechnic Institute, 1984, no.213, Series «Electric power industry and automation of power plants», no.12, pp. 3-6. (Rus).

Received 27.12.2018

I.V. Nizhevskyi ${ }^{1}$, Candidate of Technical Science,

V.I. Nizhevskyi ${ }^{1}$, Candidate of Technical Science, Associate Professor,

${ }^{1}$ National Technical University «Kharkiv Polytechnic Institute», 2, Kyrpychova Str., Kharkiv, 61002, Ukraine,

phone+380 57 7076977, e-mail: victornizhevski@gmail.com

How to cite this article:

Nizhevskyi I.V., Nizhevskyi V.I. Calculation estimation of overvoltage on insulation of the equipment of a substation at the lightning strike in its lightning arrester. Electrical engineering \& electromechanics, 2019, no.3, pp. 67-73. doi: 10.20998/2074-272X.2019.3.11. 